\title{
Economic and environmental benefits of converting industrial processes to district heating
}

\author{
Danica Djuric Ilic and Louise Trygg
}

Linköping University Post Print

Tweet

N.B.: When citing this work, cite the original article.

Original Publication:

Danica Djuric Ilic and Louise Trygg, Economic and environmental benefits of converting industrial processes to district heating, 2014, Energy Conversion and Management, (87), 305317.

http://dx.doi.org/10.1016/j.enconman.2014.07.025

Copyright: Elsevier

http://www.elsevier.com/

Postprint available at: Linköping University Electronic Press

http://urn.kb.se/resolve?urn=urn:nbn:se:liu:diva-106898 


\title{
Economic and environmental benefits of converting industrial
}

\section{processes to district heating}

\author{
Danica Djuric Ilic ${ }^{\mathrm{a}, ~}$, Louise Trygg ${ }^{\mathrm{a}}$ \\ a Division of Energy Systems, Department of Management and Engineering, Linköping University, \\ SE-581 83 Linköping, Sweden
}

\begin{abstract}
The aim of this study was to analyse the possibilities of converting industrial processes from electricity and fossil fuels to district heating in 83 companies in three Swedish counties. Effects on the local district heating systems were explored, as well as economic effects and impacts on global emissions of greenhouse gases. The study was conducted considering two different energy market conditions for the year 2030.
\end{abstract}

The results show that there is a potential for increasing industrial district heating use in all analysed counties. The greatest potential regarding percentage is found in Jönköping, where the annual district heating use in the manufacturing companies could increase from $5 \mathrm{GWh}$ to $45 \mathrm{GWh}$. The annual industrial district heating use could increase from $84 \mathrm{GWh}$ to $168 \mathrm{GWh}$ in Östergötland and from $14 \mathrm{GWh}$ to $58 \mathrm{GWh}$ in Västra Götaland. The conversion of the industrial production processes to district heating would lead to district heating demand curves which are less dependent on outdoor temperature. As a result, the utilization period of the base load plants (above all of the combined heat and power plants) would be prolonged; this would decrease district heating production costs due to the increased income from the electricity production. The energy costs for the industrial companies decrease after the conversions as well. Furthermore, the increased electricity production in the combined heat

\footnotetext{
* Corresponding author. Tel. +46-13-281114; fax: +46-13-281788

E-mail address: danica.djuric.ilic@liu.se (D. Djuric Ilic)
} 
and power plants, and the decreased electricity and fossil fuel use in the industrial sector opens up a possibility for a reduction of global greenhouse gas emissions. The potential for the reduction of global greenhouse gas emissions is highly dependent on the alternative use of biomass and on the type of the marginal electricity producers. When the marginal effects from biomass use are not considered, the greenhouse gas emissions reduction is between 10 thousand tonnes of $\mathrm{CO}_{2 \mathrm{eq}}$ and 58 thousand tonnes of $\mathrm{CO}_{2 \mathrm{eq}}$ per year, depending on the county and the type of marginal electricity production plants. The highest reduction is achieved in Östergötland. However, considering that biomass is a limited resource, the increase of biomass use in the district heating systems may lead to a decrease of biomass use in other energy systems. If this assumption is included in the calculations, the conversion of the industrial processes to district heating still signify a potential for reduction of greenhouse gas emissions, but this potential is considerable lower.

\section{Abbreviations}

BCHP, biomass-fuelled combined heat and power; $\mathrm{CCP}$, coal condensing power; CHP, combined heat and power; $\mathrm{CO}_{2}$, carbon dioxide; $\mathrm{COP}$, coefficient of performance; $\mathrm{DH}$, district heating; DHS, district heating system; GHG, greenhouse gas; HOB, heat-only boiler; EM, energy market; EMS, energy market scenario; ENPAC, Energy Price and Carbon Balance tool; FTD, Fischer-Tropsch diesel; IEA, International Energy Agency; MeHLA, Method for Heat Load Analysis; NGCC, natural gas combined cycle; NGCHP, natural gas-fuelled combined heat and power; RES-E, electricity produced from renewable energy sources; WEO-np, "New Policies Scenario"; WEO-450, “450 scenario".

\section{Keywords}

District heating; Energy cooperation; Industry 


\section{Introduction}

District heating (DH) can play a decisive role in a future sustainable society [1], [2], [3]. Beside the possibility of using a variety of different fuels (waste, biomass...), one of the largest benefits of DH is the possibility of utilizing combined heat and power (CHP) production technology [4], [5], [6]. Due to high investment costs and low operating costs, CHP plants in a DH system (DHS) are usually used as base load production plants. Despite this, large biomass-fuelled CHP (BCHP) plants are commonly taken out of operation during the summer, since the minimum operating effect of these plants is often higher than the load demand curves in the DHS then. Some of the solutions to this problem may be to introduce long-thermal storage into the DHS [7] or to introduce DH-driven absorption-cooling production for the purposes of comfort-cooling, since this cooling demand is highest during the summer [8]. Furthermore, due to global warming, DH demand in the future is expected to decrease. This means that DH producers will face new challenges and need to develop new business strategies [9].

New ways to use $\mathrm{DH}$, and the possibilities to decrease $\mathrm{DH}$ production costs by including by-production of other energy carriers than electricity, have been of great interest during the last years. In order to achieve this, possibilities for cooperation between DHSs and other energy systems has been studied. One of the examples is cooperation between a DHS and industrial sector. This cooperation can be achieved in two possible ways: by delivering industrial waste heat into the DHS or by converting industrial processes to $\mathrm{DH}$.

The economic and environmental benefits of utilization of industrial waste heat into DHSs are shown to be case-specific [10], [11]. If the waste heat reduces the DH production in CHP plants, the revenues from electricity production in those plants would decrease, which would make this business strategy not profitable for DH producers [11]. Furthermore, the reduction 
of the electricity production in the CHP plants would also lead to an increase marginal electricity production (this term is explained more in Ådahl and Harvey [12]) in the power sector. Thus, if the marginal electricity is produced in coal condensing power (CCP) plants this would lead to an increase in global carbon dioxide $\left(\mathrm{CO}_{2}\right)$ emissions [10].

On the other hand, the second way of cooperation (the cooperation by converting industrial processes to $\mathrm{DH}$ ) is often a cost-effective and energy-efficient measure, which results in an increased utilization of CHP plants in the local DHS, and subsequently leads to a reduction of global $\mathrm{CO}_{2}$ emissions. Industrial heat demand is generally categorized in three different temperature levels (see section 4.4 in Frederiksen and Werner [13]): low temperature level (below $100^{\circ} \mathrm{C}$ ), medium temperature level (between $100^{\circ} \mathrm{C}$ and $400^{\circ} \mathrm{C}$ ) and high temperature level (above $400^{\circ} \mathrm{C}$ ). The major low temperature demand can be found in the manufacture of food and tobacco products, manufacture of machinery and equipment, manufacture of chemicals and chemical products, and manufacture of textiles [13]. Some of the industrial processes which required low temperature heat are washing, rinsing, food preparation, drying, and heating. The low temperature heat demand can be supplied from local DHSs. However, the possibility to supply the demand depends on the temperature required and on the variations of DH supply temperature during the year; this is more discussed in the section 3.1. In 2007, the low temperature demand amounted to $30 \%$ of the annual total industrial heat demand in the 27 EU countries (approximately $3.12 \mathrm{EJ}$ [13]).

A number of previous studies have been performed in order to analyse the benefits and the possibilities of increasing DH use in the Swedish industrial sector; the share of DH use in the total energy use in the industrial sector in Sweden (approximately $150 \mathrm{TWh}$ ) was only $4 \%$ in 2012, while the shares of electricity and fossil fuels were $36 \%$ and $23 \%$ respectively [14]. Difs et al. [15] analysed how conversion of industrial processes from electricity and fossil fuels to DH in 34 Swedish industries from different sectors of trade would influence the DH 
load duration curves in the local DHSs. The results showed that the conversion would lead to a DH demand curve which is less dependent on outdoor temperature, and thus would increase the utilization of the base production plants (CHP plants). The electricity use and the fossil fuel use in the analysed industries would decrease as well. When it is assumed that the increased electricity production in the CHP plants and the decreased electricity use in the industrial companies would reduce marginal electricity production in the power sector (electricity production in CCP plants), there is also a potential for reduction of global $\mathrm{CO}_{2}$ emissions. Trygg and Amiri [16] analysed the most cost-effective technology for cooling by comparing DH-driven absorption-cooling with vapour compression chillers for seven industrial companies in Norrköping, Sweden, where the base production plant is a waste-fuelled CHP plant. When higher European electricity prices are considered, the absorption-cooling was shown to be a more cost-effective solution. The conversion to absorption-cooling production would also result in reduced global $\mathrm{CO}_{2}$ emissions, when $\mathrm{CCP}$ plants are assumed to be the marginal electricity sources. In order to make the conversion to DH more economically attractive choice for the industry, Difs and Trygg [17] suggested applying the marginal costs for DH production as DH tariffs for the industry. The research was done through a case study which included the local DHS in Linköping, Sweden, and eight local industrial companies. The results show that this business strategy would lead to economic benefits not only for the industry but also for the DH providers, since it would result in higher electricity production in the DHS and subsequently in higher revenues from electricity sold. When CCP plants are assumed to be the marginal electricity sources, this strategy opens up a possibility for a reduction of global $\mathrm{CO}_{2}$ emissions [17] as well. Henning and Trygg [18] recognized the conversion of industrial processes to DH as a vital measure when redirecting the energy systems toward sustainability. They also pointed out that replacing the electricity by $\mathrm{DH}$ produced in CHP plants would have a dual impact on the 
power sector; the marginal electricity production would be reduced not only because of the decreased electricity use in the industry, but also because of the increased electricity production in the CHP plants. The reduced marginal electricity production would subsequently lead to lower global $\mathrm{CO}_{2}$ emissions.

\subsection{Aim}

The aim of this paper is to analyse the potential for converting production processes and support processes from electricity and fossil fuels to $\mathrm{DH}$ in the Swedish manufacturing sector. The paper also analyses the potential for more efficient operation of DH production plants in local DHSs when the DH use in the researched industry is increased. Both economic consequences as well as impacts on global greenhouse gas (GHG) emissions are studied considering two different energy market (EM) conditions.

Eighty three manufacturing companies in three Swedish counties were used as the case studies, but the results may be relevant also for other manufacturing companies from the same branches as those included in this study. The objective of the study was to provide information which can be used by industrial and $\mathrm{DH}$ companies when considering possibilities for cooperation, and as a decision basis for policymakers when considering different strategies for climate change mitigation.

\section{Methodology}

The study includes three counties: Västra Götaland, Östergötland and Jönköping. Information about the manufacturing industry in the counties was collected from energy efficiency audits performed during the last few years. The industrial support and production processes that could be converted to $\mathrm{DH}$ were identified and data about the characteristics of those processes (e.g. temperature levels and seasonal variations) were collected from the audits. The expected annual DH demand for those processes were adjusted to the time division 
which is divided into 88 periods (Table 8; Appendix). The division reflects the seasonal variation of the existing DH load duration curves in the local DHSs [19], [20]. The effects of the conversion of industrial processes to $\mathrm{DH}$ on the existing $\mathrm{DH}$ load duration curves were analysed using the Method for Heat Load Analysis (MeHLA) which was developed at Linköping University by Difs et al. [15].

When changes of energy costs for industry and changes of global GHG emissions caused by the conversion were estimated, sensitivity analyses on different EM conditions were performed. For that purpose two future EM scenarios (EMSs) for Sweden were developed using a tool called ENPAC (Energy Price and Carbon Balance tool) [21], [22], [23].

\subsection{Data collection and assumptions for the year 2030}

The analyses were applied to 83 manufacturing companies in three counties located in the south of Sweden: Västra Götaland, Östergötland and Jönköping (Figure 1). The reason for choosing counties situated in the south of Sweden is because the annual outdoor temperature variation is more significant in the south of Sweden than in the north of Sweden and this leads to a less efficient utilization of the base production plants in the DHSs. Furthermore, the number of industries located in the south of Sweden is higher, and in the counties included in this study a number of DH networks already exist. 


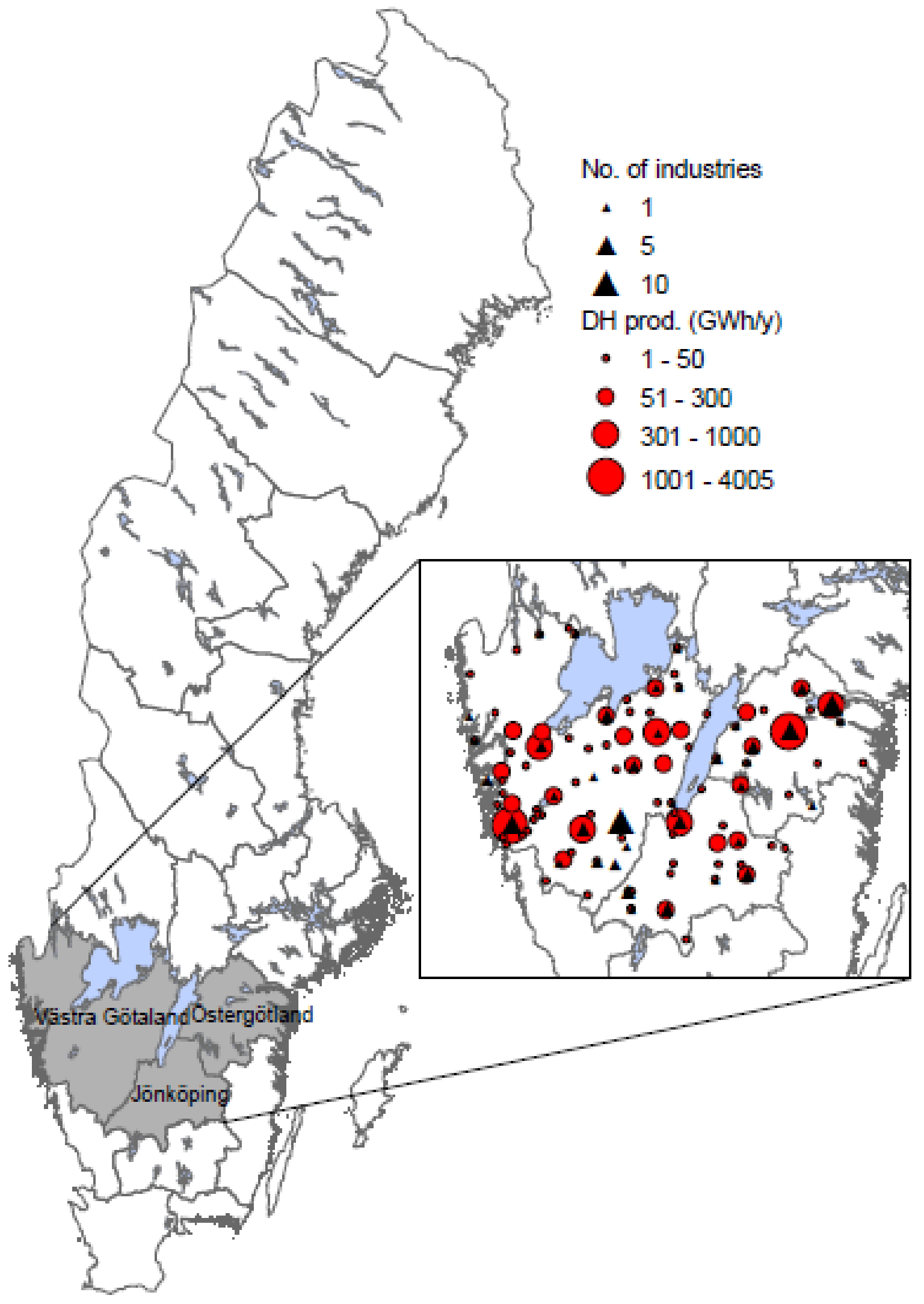

Figure 1. Overview of the positions of DHSs and industries included in the study. (No. of industries $=$ number of industries $; \mathrm{DH}$ prod. $=\mathrm{DH}$ production $)$ 
During the year 2011, the fuel mixes in the DHSs in the analysed counties differed significantly, as did the present DH production technologies (Figures 2 and 3; [24]). There are approximately $60 \mathrm{DH}$ networks in Västra Götaland, and approximately 10 and $20 \mathrm{DH}$ networks in Östergötland and Jönköping. In this study it is assumed that the DH networks in Västra Götaland, Östergötland and Jönköping counties would be connected in large regional DHSs by the year 2030. This assumption has been taken based on the experience how fast Stockholm's DHS developed from small DH networks to a large regional network [25]. This is the reason for choosing to perform the analysis for the time period from 2030 to 2040 as well. It is also assumed that the waste amounts in the counties would follow the population trend (according to ITPS [26], by the year 2030 the populations would increase by $1.2 \%$ in Västra Götaland, and by $1.1 \%$ in Östergötland and Jönköping counties) and that all the available waste would be used for CHP production. It is also assumed that the capacity of the BCHP plants in the DHSs (and consequently DH production in those plants) would be $30 \%$ higher than today, that plants fuelled by coal would be phased out, and that the amount of waste heat delivered to the DHSs would be unchanged. Since DH production in natural gas-fuelled CHP (NGCHP) plants may be characterized not only by high economic benefits but also by a potential to decrease global GHG emissions [27], [28], [29], and since a well-developed natural gas supply network already exists in Västra Götaland, it is also assumed that the capacity of the existing NGCHP plant in this county would be unchanged. Oil is expected to be used only for peak demand during the winter (it is assumed that $2.5 \%$ of annual DH production would be produced in oil-fuelled heat-only boilers). Furthermore, according to Göransson et al. [30] the DH demands in the DHSs would probably be $10 \%$ lower compared to the present DH demands. Finally, the characteristics of the regional DHSs in the year 2030 were calculated based on the assumptions presented above (Figure 2, Figure 3 and Table 1). 


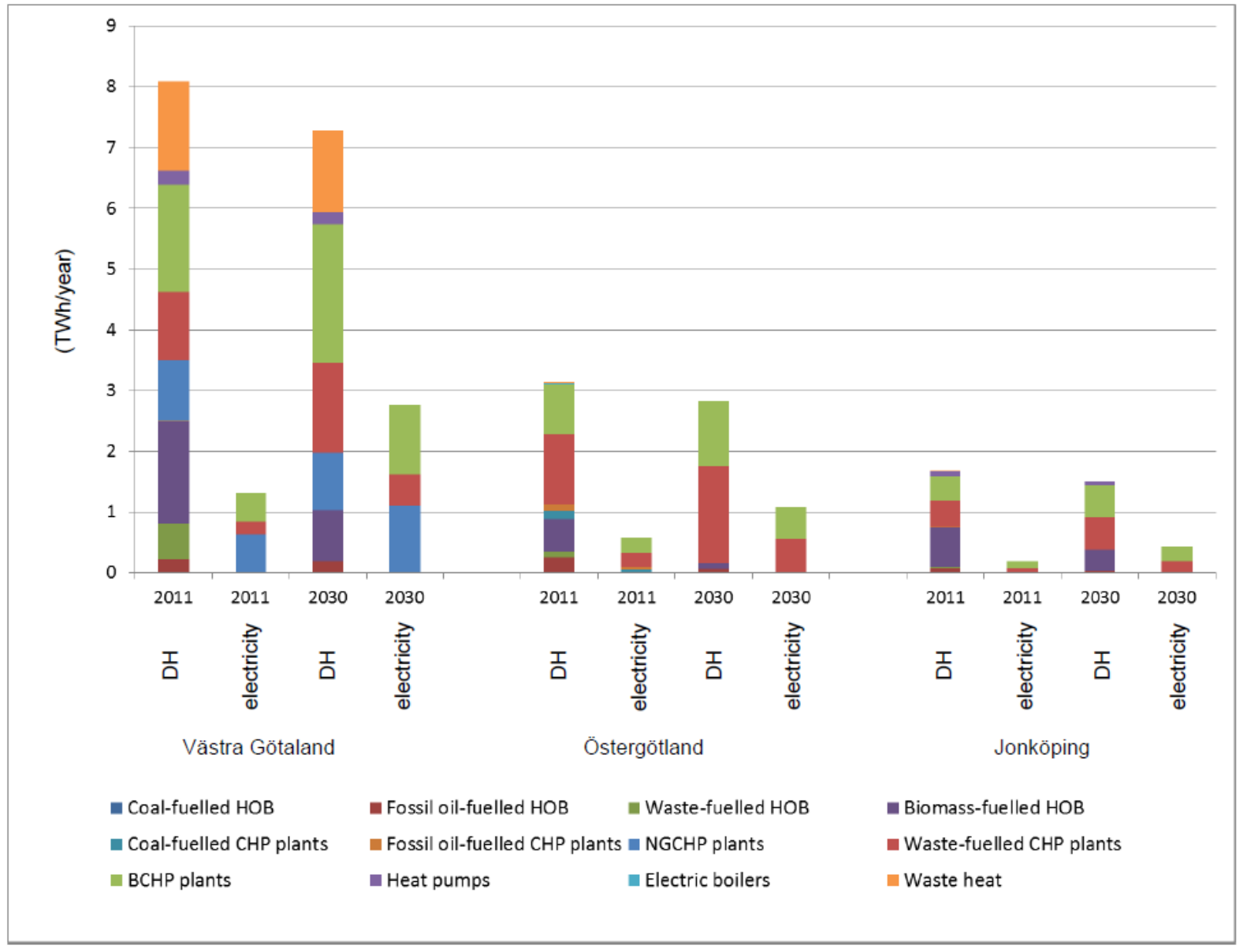

Figure 2. The annual DH and electricity productions with different technologies in the DHSs in Västra Götaland, Östergötland and Jönköping counties. (HOB = heat-only boiler). The data for the year 2011 was found in Svensk Fjärrvärme [24], while the data for the year 2030 were calculated based on the described assumptions. 


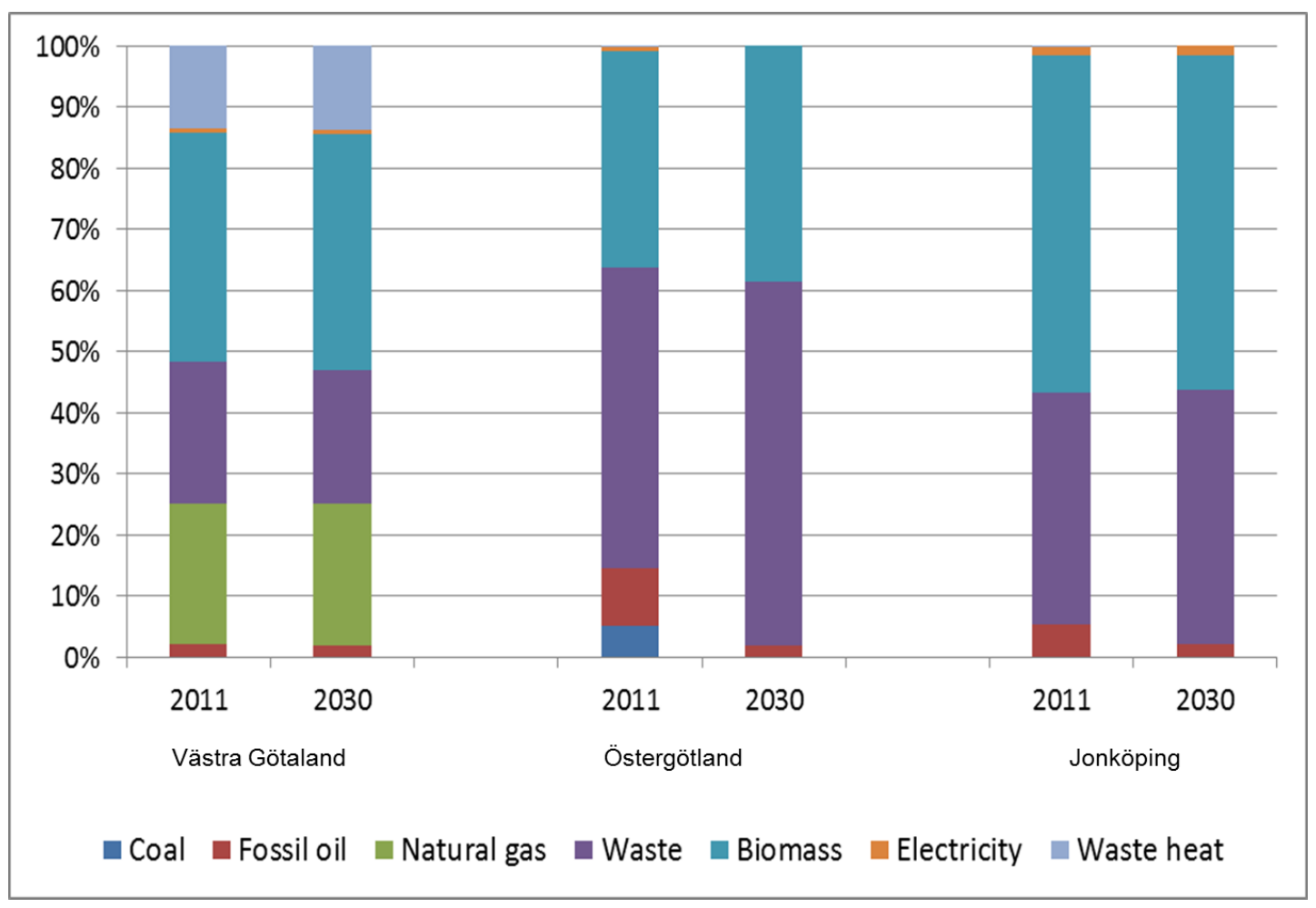

Figure 3. The annual fuel mixes used for DH and electricity production in the DHSs. The data for the year 2011 were found in Svensk Fjärrvärme [24], while the data for the year 2030 were calculated based on the described assumptions.

Table 1. The total power-to-heat ratio of the DHS $\left(\alpha_{\mathrm{ekv}}\right)$ and the share of DH produced in CHP plants.

\begin{tabular}{|c|c|c|c|c|c|c|c|}
\hline & & \multicolumn{2}{|c|}{ Västra Götaland } & \multicolumn{2}{|c|}{ Östergötland } & \multicolumn{2}{|c|}{ Jönköping } \\
\hline Year & & 2011 & 2030 & 2011 & 2030 & 2011 & 2030 \\
\hline$\alpha_{\mathrm{ekv}}$ & & 0.162 & 0.379 & 0.182 & 0.387 & 0.110 & 0.294 \\
\hline $\begin{array}{l}\text { The share of DH } \\
\text { produced in CHP plants }\end{array}$ & $(\%)$ & 48 & 64 & 71 & 94 & 51 & 69 \\
\hline
\end{tabular}

The data about the industrial companies were compiled from energy efficiency audits that have been performed during the period 2010 - 2012. The energy efficiency audits were collected by the Division of Energy Systems at Linköping University and the Energy Agency of South East Sweden. Due to a non-disclosure agreement the industries included in the study 
are not presented by names but only by sector of trade (Table 2). Despite the fact that most of the industrial companies are located near a DHS in their respective counties (Figure 1), only $28 \%$ of them are connected to the DHS; 13 of the industrial companies are connected in Västra Götaland, 10 in Östergötaland, and 5 in Jönköping.

Table 2. The industries included in the study.

\begin{tabular}{|c|c|c|c|c|c|}
\hline 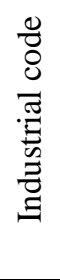 & Branch & 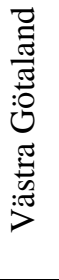 & 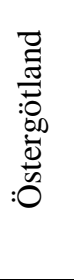 & 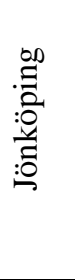 & $\begin{array}{l}\overline{0} \\
\tilde{\Xi} \\
0 \\
\overline{0} \\
\overline{0}\end{array}$ \\
\hline 10 & Manufacture of food products & 4 & 3 & 1 & 9 \\
\hline 13 & Manufacture of textiles & 4 & & & 4 \\
\hline 15 & Manufacture of leather and related products & 1 & & & 1 \\
\hline 16 & $\begin{array}{c}\text { Manufacture of wood and of products of wood and cork, except } \\
\text { furniture; manufacture of articles } \\
\text { of straw and plaiting materials }\end{array}$ & 1 & & 2 & 3 \\
\hline 20 & Manufacture of chemicals and chemical products & 3 & 3 & & 6 \\
\hline 21 & $\begin{array}{l}\text { Manufacture of basic pharmaceutical products and } \\
\text { pharmaceutical preparations }\end{array}$ & & 2 & & 2 \\
\hline 22 & Manufacture of rubber and plastic products & 6 & 2 & 1 & 9 \\
\hline 23 & Manufacture of other non-metallic mineral products & 5 & & 1 & 6 \\
\hline 24 & Manufacture of basic metals & & 1 & 2 & 3 \\
\hline 25 & $\begin{array}{c}\text { Manufacture of fabricated metal products, except machinery and } \\
\text { equipment }\end{array}$ & 4 & 4 & 5 & 13 \\
\hline 27 & Manufacture of electrical equipment & 2 & & & 3 \\
\hline 28 & Manufacture of machinery and equipment n.e.c. & 5 & 4 & 3 & 12 \\
\hline 29 & Manufacture of motor vehicles, trailers and semi-trailers & 3 & & & 3 \\
\hline 30 & Manufacture of other transport equipment & 1 & 1 & 1 & 3 \\
\hline 31 & Manufacture of furniture & 1 & & & 1 \\
\hline 32 & Other manufacturing & 1 & & 1 & 2 \\
\hline 33 & Repair and installation of machinery and equipment & 2 & 3 & & 5 \\
\hline & Total & 43 & 23 & 17 & 83 \\
\hline
\end{tabular}

\subsection{Method for heat load analysis (MeHLA)}

Processes which can be converted to $\mathrm{DH}$ were identified and examined according to heat demand and time-dependency. After this, heat load duration curves for those processes and the present $\mathrm{DH}$ load duration curves for the industrial processes (for industrial companies which already use DH) were adjusted to the chosen time division (see beginning of the 
section 2). For each industrial company studied, the present and the predicted new DH load duration curves for each separate process (drying, space heating, hot tap water, melting, process heating and other) were introduced as input data to the MeHLA [15]. Some of the outputs from the MeHLA are DH load duration curves for the different unit processes for all of the industrial companies together. These outputs offer a possibility to identify which one of the processes has the highest potential to increase DH use in the industrial sector and which one of the processes has the highest potential to increase DH production in the base production plants during the summer. DH load duration curves for each respective industrial company, and DH load duration curves for each industrial sector of trade, are also outputs from the MeHLA. The outputs make it possible to identify which type of industry has the highest potential to increase $\mathrm{DH}$ use. The results can also be presented as monthly energy demands.

\subsection{Development of future EM scenarios (EMSs) for Sweden using ENPAC}

Two EMSs for Sweden for the year 2030 were developed using a tool called ENPAC [21], [22], [23]. The input data that were applied to the tool (Table 3) were world market fossil fuel prices, $\mathrm{CO}_{2}$ charges, and support for electricity produced from renewable energy sources (RES-E). The world market fossil fuel prices and the $\mathrm{CO}_{2}$ charges came from two future global EMSs which have been developed by the International Energy Agency (IEA) and described in "World Energy Outlook 2011" [31]. The first one is "New Policies Scenario" (EMS WEO-np) which is a scenario based on the recent government policy commitments. The second one is a scenario based on the energy policies which would enable the $2^{\circ} \mathrm{C}$ target (more explained in Pachauri and Reisinger [32]) to be reached at a reasonable cost, known as "450 Scenario" (EMS WEO-450) [31]. The RES-E-support was based on the average values for Europe. 
When the electricity prices were calculated, the total generation cost (including the investment costs and the present values of the plants) in the "build" marginal plants (the term is explained more in Adahl and Harvey [12]) was considered. Two "build" margins for the year 2030 were identified: CCP plants and natural gas combined cycle (NGCC) plants.

Biomass will probably become even more subject to competition in the future, which would result in an increase of biomass price. According to Axelsson and Harvey [21], [22], the high-volume users with the greatest willingness to pay for the biomass will be the pricesetting groups for biomass in the future. Based on the input data to the ENPAC tool, two high-volume users of biomass were identified: CCP plants where biomass can be co-fired, and plants for Fischer-Tropsch diesel (FTD) production. When the biomass price was calculated, the costs for biomass transportation were included as well. It was assumed that the average cost for biomass transportation is $€ 4.2 / \mathrm{MWh}[33]$.

The waste fuel price was calculated considering waste fuel fired condensing plants as the marginal users of the waste fuel (this is explained in more details in Axelsson and Pettersson [23]).

When the DH prices were calculated a cost-based pricing principle was applied. This pricing principle estimates a DH price level considering both the heat generation costs and the heat distribution costs. The heat generation costs were calculated as annual average DH production costs considering the production technologies in the DHSs (Figure 2; year 2030). All production costs (electricity and fuel costs including taxes and fees, and operation and maintenance costs) were included in the calculations, as well as the revenues from the co-produced electricity; the revenues were included as negative costs. The heat distribution costs consist of four different categories of cost (see section 11.4 in Frederiksen, and Werner [13]): the distribution capital cost (which represent annual repayments of investment capital), 
the distribution heat loss cost, the distribution pressure loss cost, and the distribution maintenance cost. The distribution capital cost is parameter which is not known before building a DH network. Frederiksen and Werner [13] estimated this cost for 134 existing Swedish DH networks and presented them on a curve as specific capital costs (Figure 11.9 in Frederiksen and Werner [13]). Based on this curve, two different specific distribution capital costs were assumed in this study: $€ 5 / \mathrm{GJ}$ and $€ 10 / \mathrm{GJ}$; considering these two costs two different DH price levels were calculated (see Table 3). When the distribution heat loss cost was calculated it was assumed that the relative heat losses in the DHSs are about $15 \%$ (see section 5.3.3 in Frederiksen and Werner [13]), and when the distribution pressure loss cost was estimated it was assumed that the relative demand for electricity for pumping is about $0.5 \%$ of the heat delivery (section 10.3 .2 in Frederiksen and Werner [13]). The specific distribution maintenance cost is assumed to be as large as $1 \%$ of the specific distribution capital cost (see section 11.4 in Frederiksen and Werner [13]). 
Table 3. EMSs for the year 2030. The world market fossil fuel prices and the $\mathrm{CO}_{2}$ charges were taken from "World Energy Outlook 2011" [31]. The RES-E-support was based on the average values for Europe.

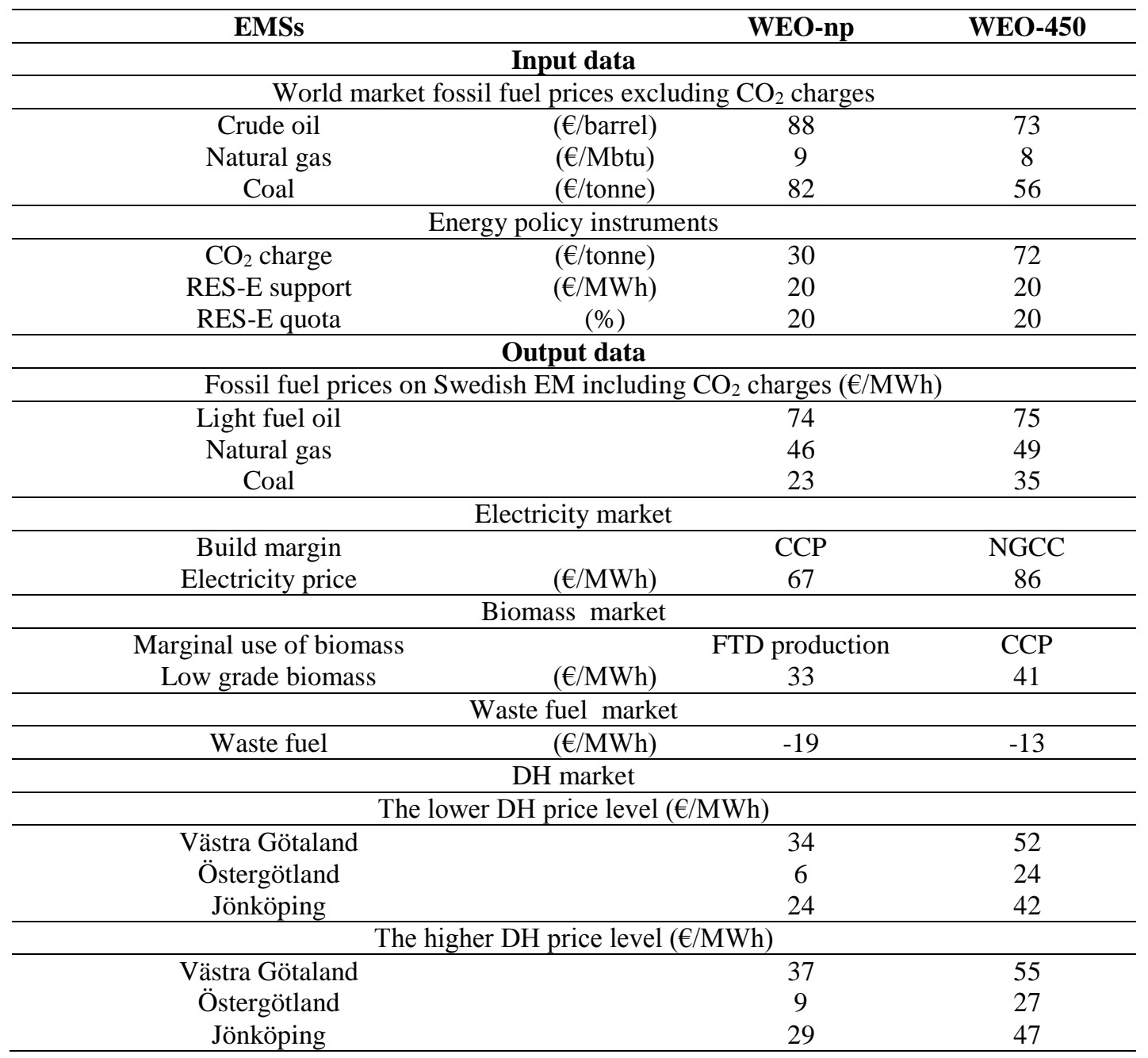

\subsection{Estimating the effects on global GHG emissions}

The influences on global GHG emissions have been analysed considering the entire life cycle of the fuels. The values of GHG emissions are presented as $\mathrm{CO}_{2}$ equivalent $\left(\mathrm{CO}_{2 \mathrm{eq}}\right)$ emissions (Table 4). The well-to-gate and combustion GHG emissions factors for the fossil oil and natural gas have been found in Edwards et al. [34]. The assumptions during the conversion to $\mathrm{CO}_{2 \text { eq }}$ are explained in Djuric Ilic et al. [35]. GHG emissions caused by electricity use in the industrial sector are estimated considering the "build" margin power plants (see section 2.3). 
The analysis is performed based on two different assumptions considering the future biomass availability. In the first part of the analysis, where it is assumed that the biomass is an unlimited resource, only GHG emissions from the biomass transportation are considered (Table 4). In the second part of the analysis, the marginal effects of the biomass use are considered assuming that an increased biomass use in the DHSs would lead to a decreased biomass use in plants for FTD production (marginal users of biomass in EMS WEO-np; Table 3) or to a decreased biomass use in CCP plants where biomass can be co-fired (marginal users of biomass in EMS WEO-450; Table 3). This will result in increased GHG emissions in the transport sector (EMS WEO-np; Table 4) or in increased GHG emissions in the power sector (EMS WEO-450; Table 4). Data about those GHG emissions were found in Axelsson and Harvey (2010), while data about GHG emissions during biomass transportation, waste combustion, and waste transportation were taken from Djuric Ilic et al. [35].

Table 4. GHG emissions factors used in the study $\left(\mathrm{CO}_{2 \mathrm{eq}} \mathrm{kg} / \mathrm{MWh}\right)$.

\begin{tabular}{|c|c|c|}
\hline & WEO-np & WEO-450 \\
\hline Light fuel oil & 320 & 320 \\
\hline Natural gas & 242 & 242 \\
\hline Waste & 102 & 102 \\
\hline \multicolumn{3}{|l|}{ Electricity market } \\
\hline Build margin & $\mathrm{CCP}$ & NGCC \\
\hline Marginal Electricity & 679 & 345 \\
\hline \multicolumn{3}{|l|}{ Biomass market } \\
\hline Marginal use of biomass & FTD production & $\mathrm{CCP}$ \\
\hline Low grade biomass & 118 & 336 \\
\hline GHG emissions from the biomass transportation & 10 & 10 \\
\hline \multicolumn{3}{|c|}{ DH market } \\
\hline \multicolumn{3}{|c|}{ DH production when biomass use is considered as $\mathrm{CO}_{2}$ emissions neutral } \\
\hline Västra Götaland & -164 & -40 \\
\hline Östergötland & -192 & -63 \\
\hline Jönköping & -134 & -41 \\
\hline \multicolumn{3}{|c|}{ DH production when marginal effects of biomass use is considered } \\
\hline Västra Götaland & -118 & 86 \\
\hline Östergötland & -146 & 63 \\
\hline Jönköping & -70 & 137 \\
\hline
\end{tabular}

were performed based on the annual DH production fuel mixes and the annual electricity and 
DH productions in the DHSs (Figure 2). It is assumed that the electricity produced would cause a reduction of the GHG emissions in the power sector by decreasing the electricity production in the "build" margin plants. As a consequence, since the electricity production per $1 \mathrm{MWh}$ DH produced is high in all DHSs (Table 1; the year 2030) the GHG emissions factors of DH production are negative in most of the analysed cases (Table 4). This means that the DH production leads to a reduction of GHG emissions in the power sectors, which are higher than the GHG emissions from the fuel combustion in the DHS. The only case where the GHG emissions of DH production are positive is when CCP plants are assumed to be the alternative users of biomass and when the marginal electricity is produced in NGCC plants. In this case the increased biomass use in the DHS, leads to an increased coal use and to increased GHG emissions in the power sector. At the same time the reduction of the GHG emissions caused by the electricity production in the DHS is lower, due to the lower GHG emissions from the marginal electricity production.

\section{Results and discussion}

The changes in energy use in the industrial companies, after the conversion of industrial processes to $\mathrm{DH}$, were estimated and presented in Table 5. The DH use in the industrial companies before and after the conversion have been divided into unit processes (Figures 4, 5 and 6).

When conversion of electricity-driven compression coolers to DH-driven absorption coolers is considered, it is assumed that the coefficient of performance (COP) of compression coolers is 3 and that the COP of absorption coolers is 0.7 [16]. As a result, the DH use for cooling production is approximately 4.2 times higher than the electricity use. In all analysed counties the potential for the conversion to DH-driven absorption coolers is found, which results in higher DH demands compared to the decreases in electricity, fossil fuel and biomass uses 
(Table 5). The ratio between the primary energy use for cooling production with DH-driven absorption coolers and the primary energy use for cooling production with electricity-driven coolers is highly dependent on the $\mathrm{DH}$ production and electricity production technologies assumed. This ratio is lower than 4.2 but it still indicates higher primary energy use for the absorption-cooling production.

Table 5. Changes in energy use in the industrial companies (GWh/year).

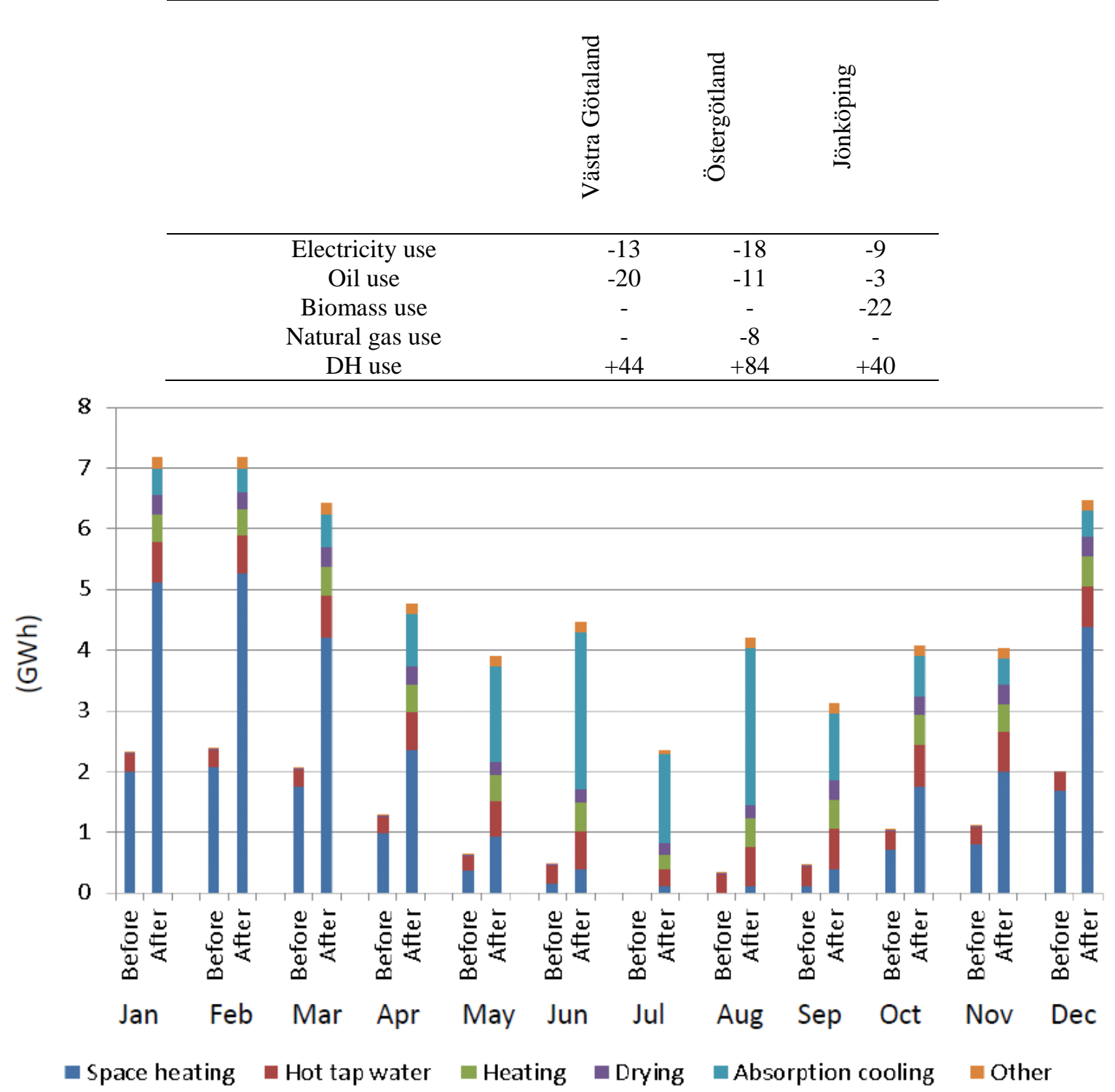

Figure 4. Monthly DH demand in different support and production processes in the industrial sector in Västra Götaland. 
The DH use in the companies in Västra Götaland has a potential to increase more than 4 times (from 14 GWh to 58 GWh annually; Table 5). Presently, more than $95 \%$ of the DH use in those industrial companies is used for space heating and hot tap water (approximately $11 \mathrm{GWh}$ annually) and there is a potential to increase this DH use by $150 \%$ (up to $27 \mathrm{GWh}$ annually). There is also a potential for using the $\mathrm{DH}$ for heating (production processes in the manufacture of food products and the manufacture of textiles), drying (production processes in the manufacture of food products) and for DH-driven absorption-cooling (comfort-cooling and process-cooling in the manufacture of rubber and plastic products). However, even after the conversion to $\mathrm{DH}$, the $\mathrm{DH}$ use for space heating and tap hot water still accounts for the largest part of the total DH use in those companies (approximately $60 \%$ ). The DH use for the heating, the drying and the cooling account for approximately $9 \%, 6 \%$ and $23 \%$ respectively (Figure 4).

Ten of the industrial companies in Östergötland are already connected to the local DHSs for the purpose of space heating and hot tap water use (Figure 1). Thus, no significant potential for DH use increase for space heating in those companies is found (Figure 5). The highest conversion potential to $\mathrm{DH}$ in this county is the conversion of the cooling in industrial processes to DH-driven absorption-cooling. This conversion potential is found in the manufacture of chemicals and chemical products, the manufacture of basic pharmaceutical products and pharmaceutical preparations, and the manufacture of rubber and plastic products. After the conversion, the largest part of the DH is still used for space heating (Figure 5). The DH use for space heating accounts for approximately $45 \%$ of the total DH use while the DH use for DH-driven absorption-cooling accounts for approximately $35 \%$ of the total DH use. The annual DH use in the industrial companies in Östergötland has a potential to increase by $100 \%$, from $84 \mathrm{GWh}$ to $168 \mathrm{GWh}$ annually. Since the largest part of the process-cooling converted to DH-driven absorption-cooling was supplied by electricity 
driven compression chillers, the conversion to $\mathrm{DH}$ results in a significant decrease of electricity use (Table 5).

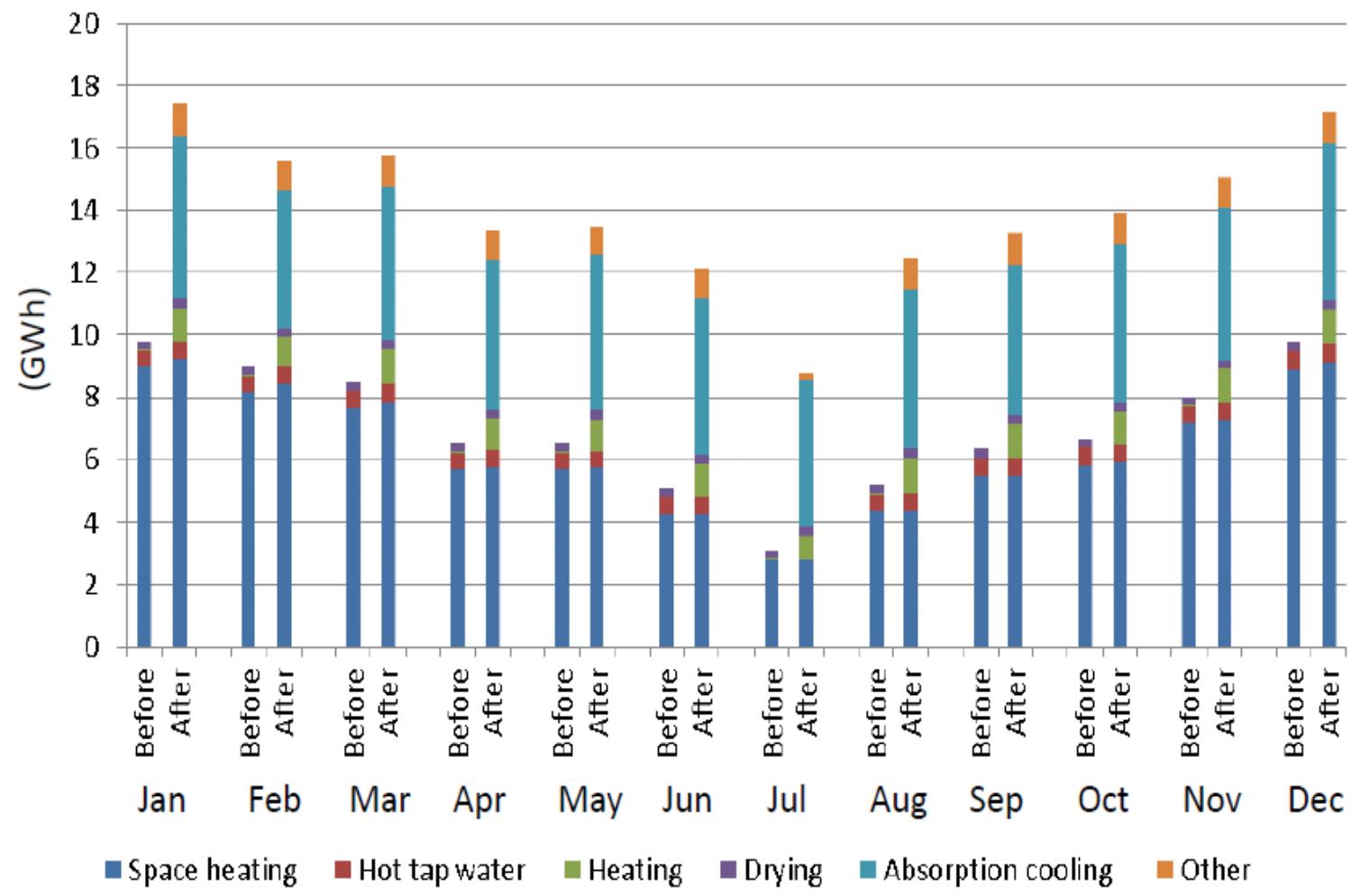

Figure 5. Monthly DH demand in different support and production processes in the industrial sector in Östergötland.

The analysed companies in Jönköping could increase their use of DH by more than 9 times (from $5 \mathrm{GWh}$ to $45 \mathrm{GWh}$ annually). The conversion to $\mathrm{DH}$ drying and $\mathrm{DH}$ space heating are the largest contributions to the possible increase in DH use (Figure 6). Those two processes account for $70 \%$ of the total $\mathrm{DH}$ use after the conversion. The potential for converting to $\mathrm{DH}$ drying (approximately $15 \mathrm{GWh}$ annually) is found in the manufacture of wood and of products of wood and cork, and in the manufacture of machinery and equipment. In this county there is a potential to decrease electricity, oil and even biomass use. The decrease in biomass use is suggested since one of the companies produce the heat in a biomass-fuelled HOB, which would be taken out of operation due to its age by the year 2030 (Table 5). 


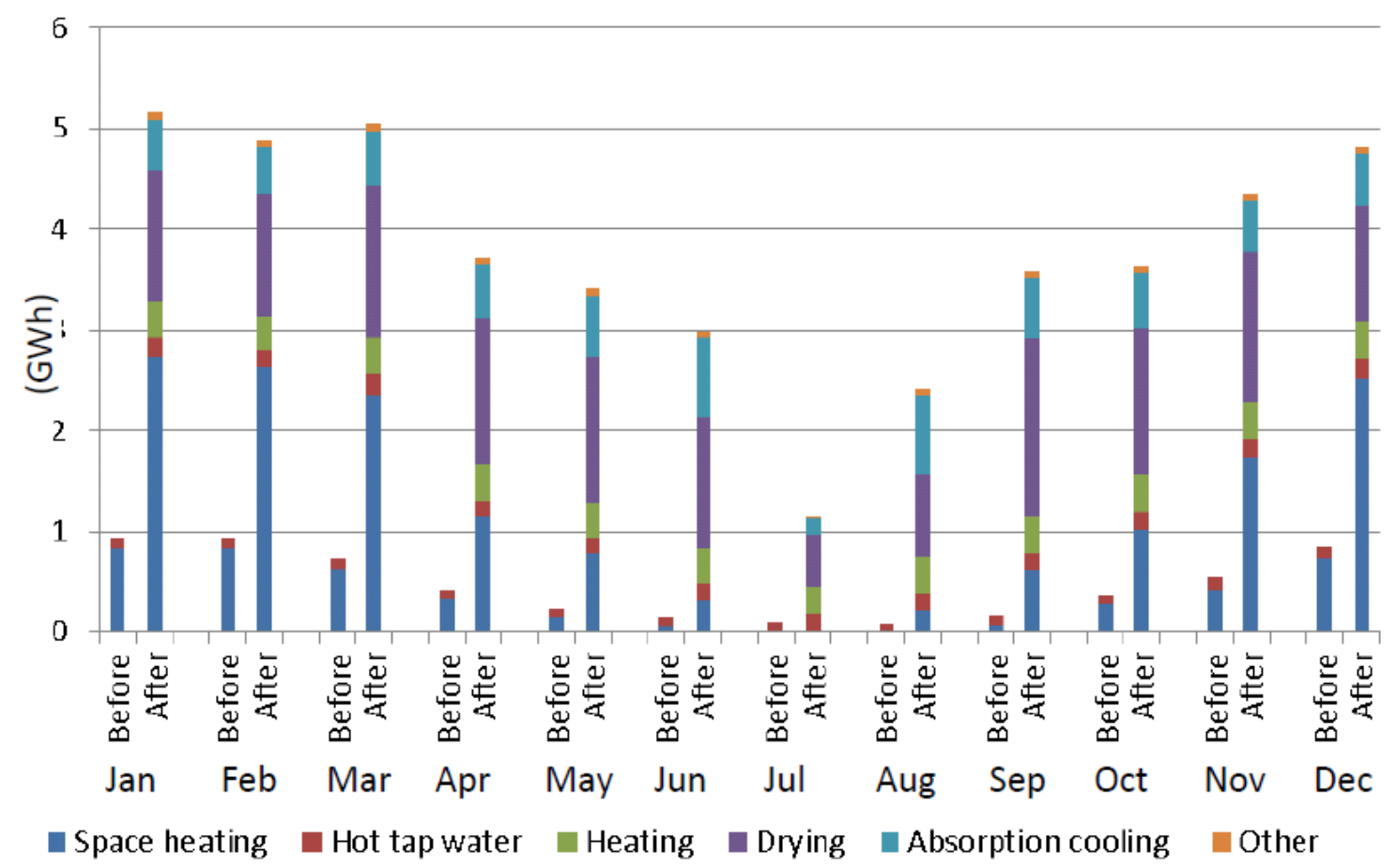

Figure 6. Monthly DH demand in different support and production processes in the industrial sector in Jönköping.

The types of processes which can be converted to $\mathrm{DH}$ differ depending on the industry (Table 6). 
Table 6. An overview of the processes which can be converted to DH in different types of industry.

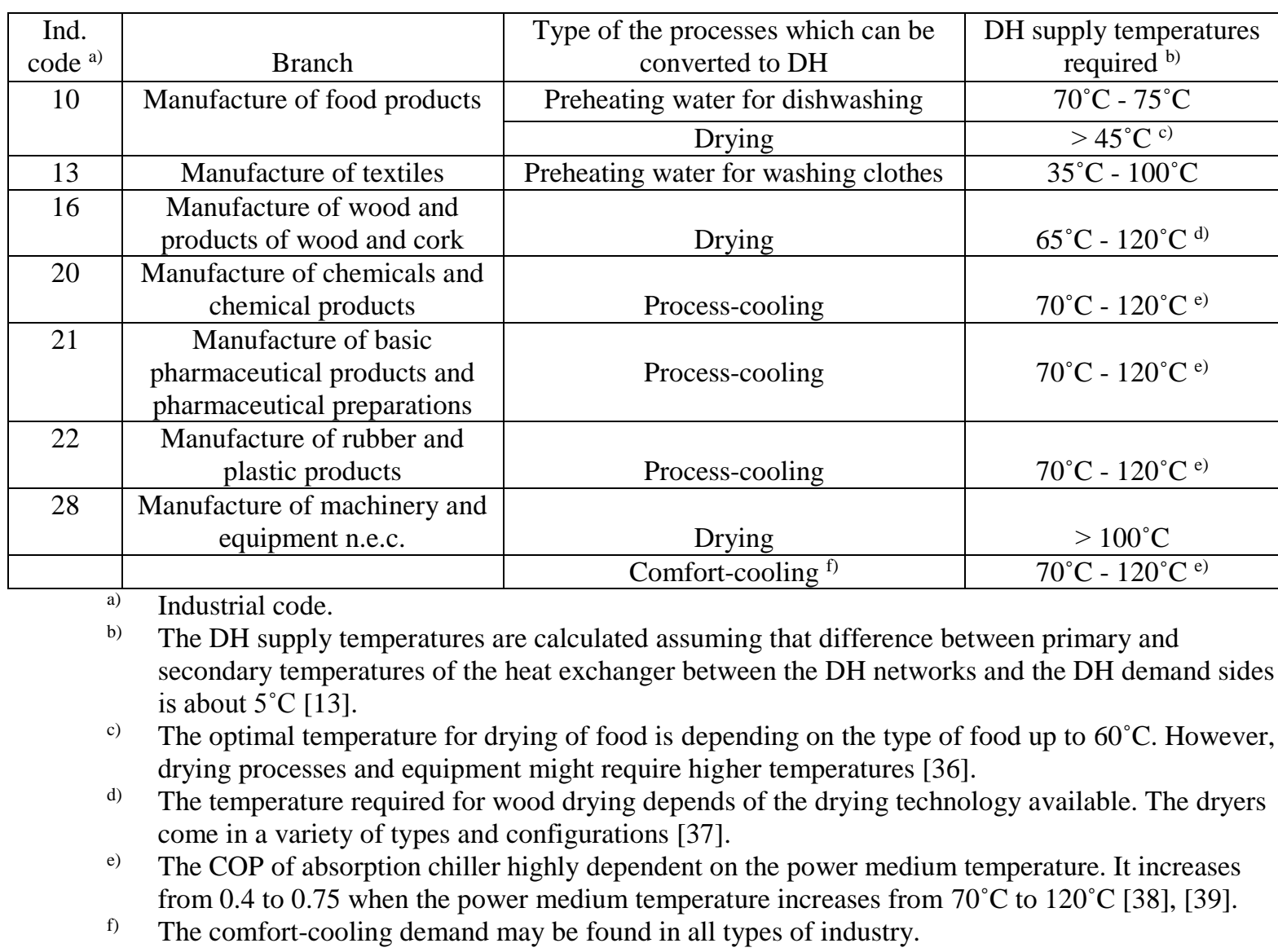

A generalization of how the processes can be converted to $\mathrm{DH}$ cannot be taken due to the variety of technologies applied.

\subsection{Influences on the local DHSs}

As the results from the study show, the present DH use in the analysed industrial companies differs significantly depending on the county (Figures 4, 5 and 6). This is due to the fact that the existing DHSs in those counties are not equally developed (Figure 1). Thus, in order to facilitate the connections of the industrial companies, the DHSs should be more developed and connected. Another change in the DHSs that will be necessary to consider is the supply temperature during the summer. The supply temperatures in Swedish DHSs usually vary during the year; it is higher during the winter $\left(120^{\circ} \mathrm{C}\right)$ and lower during the summer $\left(71^{\circ} \mathrm{C}\right)$. 
The lower supply temperature during the summer enables increased electricity efficiency (power-to-heat ratio) in the CHP plants [13]. This means that the industrial processes which required temperatures about $70^{\circ} \mathrm{C}$ or lower can be converted to $\mathrm{DH}$ without changes of the DH supply temperature. On the other hand, in order to convert the industrial processes which require temperatures higher than $71{ }^{\circ} \mathrm{C}$ (e.g. DH-driven absorption-cooling) to DH the supply temperature in the DHS during the summer must increase. For the same reason the DH use in industrial processes cannot be significantly increased if the existing DHSs were to be replaced by the fourth generation of DHSs. The fourth generation of DHSs is characterized by lower supply temperatures which subsequently results in lower heat distribution heat losses. This enable heat delivering to longer distances, and subsequently DH use in the areas with low DH demand (e.g areas with single-family houses). The lower temperature in fourth generation of DHSs also enables higher power-to-heat rations in the CHP plants and higher output capacities from: industrial residual heat, fuel gas condensation from combustion of biomass and waste, and connected solar heat collectors.

On the other hand, the increased $\mathrm{DH}$ production for the industrial processes during the summer includes an increased utilization period of the CHP plants, which may (despite the lower power-to-heat ratio in those plants) result in higher electricity production and subsequently to higher revenues from the electricity sold. The higher electricity production also opens a possibility for a reduction of global GHG emissions by decreasing the marginal electricity production in the power sector (see section 2.4). 


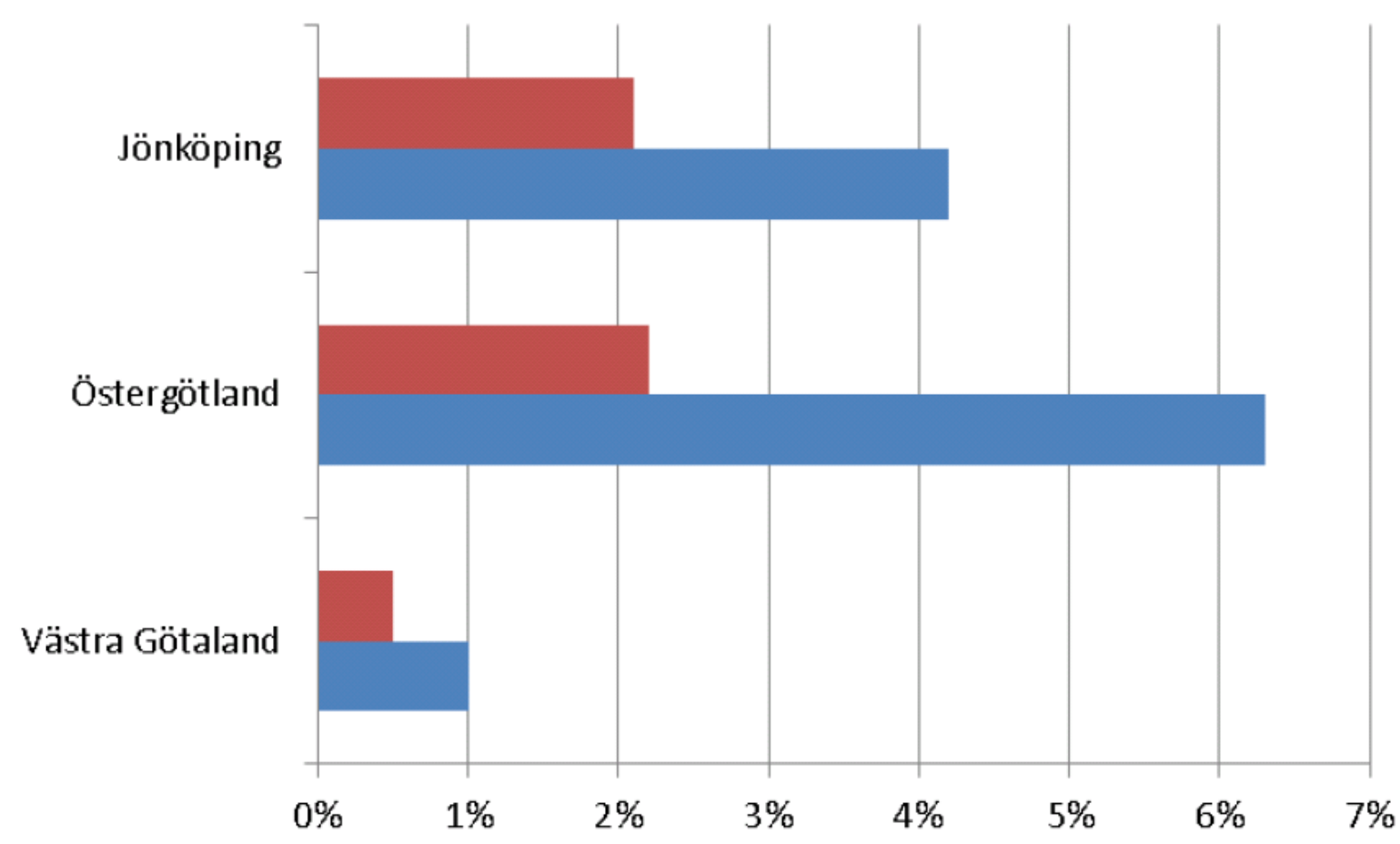

Increase in the $\mathrm{DH}$ production during the period from October to April

Increase in the $\mathrm{DH}$ production during the period from May to September

Figure 7. Influences on DH production.

The results show that the increased DH use in the industrial processes in Västra Götaland, Östergötland and Jönköping counties leads to local DH demand curves which are less dependent on outdoor temperature. During the summer vacation (which is usually in July in Sweden) the most of the analysed industrial companies close down their production processes. Despite this fact, the increase of the DH demand in the DHSs is higher during the period from May to September than during the rest of the year in all analysed counties (Figure 7). This implies that the operation of the DH production plants is carried out more efficiently and that the utilization time of the CHP plants is increased. The load duration curves for DHSs in the analysed counties before and after the conversion to DH in the industry are shown in Figures 9, 10 and 11 (Appendix). DH-driven absorption-comfort-cooling production has the highest potential to decrease seasonal 
variation of $\mathrm{DH}$ production in the DHSs, due to the fact that the cooling demand is the highest during the summer when the space heating demand is the lowest. This can be noticed in the Figure 4, where the comfort-cooling accounts for approximately $20 \%$ of the total DH use in the industrial companies in Västra Götaland.

When the increase of the electricity production was calculated the new DH demand in the industry was divided into two parts: the one which load duration curves have the same form as the DH load duration curves in the local DHS, and the rest of the DH demand (which causes the changes in the form of the DH load duration curves in the DHS). From the first part of the $\mathrm{DH}$ demand the increase of the electricity production was calculated using the $\alpha_{\mathrm{ekv}}$ of the DHS (Table 1). From the second part the DH demand the increase was calculated assuming that this DH would be produced only in CHP plants (in the NGCHP plant in Västra Götaland and in the BCHP plants in Östergötland and Jönköping counties). Due to the largest increase in DH use in Östergötland (84 GWh annually; Table 5) the increase of the electricity production in this county is the highest ( $37 \mathrm{GWh}$ annually). The increases of the electricity production in Västra Götaland and in Jönköping are $28 \mathrm{GWh}$ annually and $15 \mathrm{GWh}$ annually. Despite the fact that the increases of DH use in Västra Götaland and in Jönköping are almost equal, the increase of electricity production in Västra Götaland is twice as high. The reason for this is that there is a higher total power-to-heat ratio in the local DHS in Västra Götaland (Table 1). Furthermore, there is a higher power-to-heat ratio in the NGCHP plant (base production in the DHS in Västra Götaland) compared to the BCHP plants (base production in the DHS in Jönköping) as well.

\subsection{Economic evaluation of the conversion to DH}

Most of the industrial companies included in the study are in the areas where the DHSs are developed (see Figure 1). The existing of the large regional DHSs in the future (the 
assumption mentioned in section 2.1) will decrease costs for the connection of the analysed industrial companies to the DHSs. The investments for the connection should be made by the DH companies. The annual repayments of the investment capital for the construction of the DH networks are included in the DH prices (see section 2.3).

In order to connect the production processes into DH networks, some changes to the processes are usually required. The investments for conversion of industrial processes to DH depend not only on the type of the process but also on the technology applied. These investments cannot be calculated without detailed descriptions of the processes, which unfortunately were not available for the authors of this study. Therefore, when economic evaluation of the conversions to $\mathrm{DH}$ was performed the required investments for these changes were not included. Instead, only the energy costs changes for the industrial companies were analysed.

Table 7. Energy costs changes (thousand $€ /$ year) in the analysed industrial companies considering two different DH price levels (see section 2.3).

\begin{tabular}{ccc}
\hline EMS & WEO-np & WEO-450 \\
\hline Energy costs changes when the lower DH price is considered & \\
\hline Västra Götaland & -0.92 & -1.06 \\
Östergötlands & -1.91 & -2.03 \\
Jönköping & -0.64 & -0.80 \\
\hline EMS & WEO-np & WEO-450 \\
\hline Energy costs changes when the higher DH price is considered \\
\hline Västra Götaland & -0.12 & -0.27 \\
Östergötlands & -0.40 & -0.52 \\
Jönköping & 0.08 & -0.08 \\
\hline
\end{tabular}

Almost in all analysed cases the conversion to DH leads to a decrease in energy costs for the industrial companies (Table 7). The results are highly sensitive on the DH price level. The highest potential for decreasing the energy costs is found in Östergötland (Table 7), where waste-fuelled CHP plants produce $56 \%$ of the total DH production (year 2030; Figure 2). The decrease of the energy costs in Östergötland is two times higher than the decrease of the 
energy costs in Västra Götaland when the lower DH price level is considered, as well as when the higher DH price level is considered in combination with EMS WEO-450. When the higher DH price level is considered in combination with EMS WEO-np, the decrease of the energy costs in Östergötland is more than three times higher than the decrease of the energy costs in Västra Götaland. The conversion of industrial processes from biomass to DH was shown to be least profitable; the energy cost saving for the industrial companies in Jönköping is lowest.

Another option which can be interesting for the industrial companies, in order to improve their economy and increase their energy efficiency, is implementation of small-scale CHP production at the industrial plant site. By applying this business strategy industrial companies will have a possibility to increase their incomes by selling the co-produced electricity, and to decrease fossil fuel and electricity use for industrial processes by converting these processes to heat (excess heat from the CHP production). This business strategy is especially interesting for industrial companies whose production includes medium-temperature processes, since these processes can be supplied with steam directly from the CHP plant. However, introduction of a small-scale CHP plant in the industry would require both high investments and available space for building the plant. Therefore, this option can be interesting only for larger industrial companies. Furthermore, due to a higher flexibility in the fuel mix in the DHSs, conversion of industrial processes to DH leads to a higher security of supply compared to the implementation of small-scale CHP production at the industrial plant site. From a global perspective, considering impact on global GHG emissions and impact on the global fossil fuel use, the implementation of small-scale CHP production is a worse strategy also because of the lower electricity and total energy efficiency of these plants compared to the large CHP plants which usually exist in DHSs. 


\subsection{Effects on global GHG emissions}

When biomass is considered to be an unlimited resource (see section 2.4), the conversion of the industrial processes to DH results in a considerable reduction of GHG emissions in all analysed cases (Figure 8). Due to different GHG emission factors of DH production (Table 4) and due to different changes in energy use in the industrial sectors (Table 5), the potential GHG emissions reduction for the analysed cases differ significantly. When the marginal electricity is produced in CCP plants (WEO-np) and when the marginal effects from biomass use are not considered, global GHG emissions reduction is between 22 thousand tonnes of $\mathrm{CO}_{2 \mathrm{eq}}$ and 58 thousand tonnes $\mathrm{CO}_{2 \mathrm{eq}}$ per year, depending on the case studied. When the marginal electricity is produced in NGCC plants (WEO-450) the reduction of GHG emissions as a result of electricity production is $50 \%$ lower due to a lower GHG emissions factor from the marginal electricity production (Table 4). Thus, in the EMS WEO-450 and when the biomass is considered as an unlimited resource, global GHG emissions reduction after the conversions to DH are then between $50 \%$ and $67 \%$ lower than in the EMS WEO-np (depending on the county).

A decrease of $1 \mathrm{MWh}$ electricity use for industrial processes leads to a higher GHG emissions reduction than a decrease of $1 \mathrm{MWh}$ fossil oil or a decrease of $1 \mathrm{MWh}$ natural gas use (comparing the GHG emissions factors for marginal electricity, light fuel oil and natural gas; Table 4). Thus, when the marginal effects from biomass use are not considered, the greatest benefits for GHG emissions reduction are achieved in Östergötland (Figure 8), where the decrease of electricity use in the industrial processes (Table 5), as well as the increase of electricity produced in the DHS (see section 3.1) are highest. Furthermore, the GHG emissions factor concerning DH production in DHS in Östergötland is lowest (due to the benefits from the electricity production in CHP plants; see section 2.4 and Table 4). Consequently, when the marginal effects from biomass use are not considered the GHG 
emissions reduction achieved in Östergötland is approximately $52 \%$ (EMS WEO-np) and $50 \%$ (EMS WEO-450) higher compared to the reduction in Västra Götaland, and approximately $170 \%$ (EMS WEO-np) and $184 \%$ (EMS WEO-450) higher compared to the reduction in Jönköping.

If the alternative use of biomass is FTD production and if the marginal electricity is produced in CCP plants (the EMS WEO-np when the marginal effects from biomass use are considered), the conversion of the industrial processes to DH in the analysed counties still has potential to contribute to the reduction of global GHG emissions. However, the potential for global GHG emissions reduction is between $10 \%$ and $13 \%$ lower compared to the reduction when biomass is considered to be an unlimited resource and when the same EMS is considered.

If CCP plants are assumed to be the alternative users of biomass and if the marginal electricity is produced in NGCC plants (the EMS WEO-450 when the marginal effects from biomass use are considered), the conversion of the industrial processes to DH would not signify a considerable potential for reduction of GHG emissions. In this case the increased biomass use in the DHS, leads to an increased coal use in the power sector and consequently leads to increased GHG emissions. At the same time the benefits (considering reduction of GHG emissions) from the increased electricity production in the DHS (see section 3.1) are lower, due to the lower GHG emissions from the marginal electricity production (Table 4). 


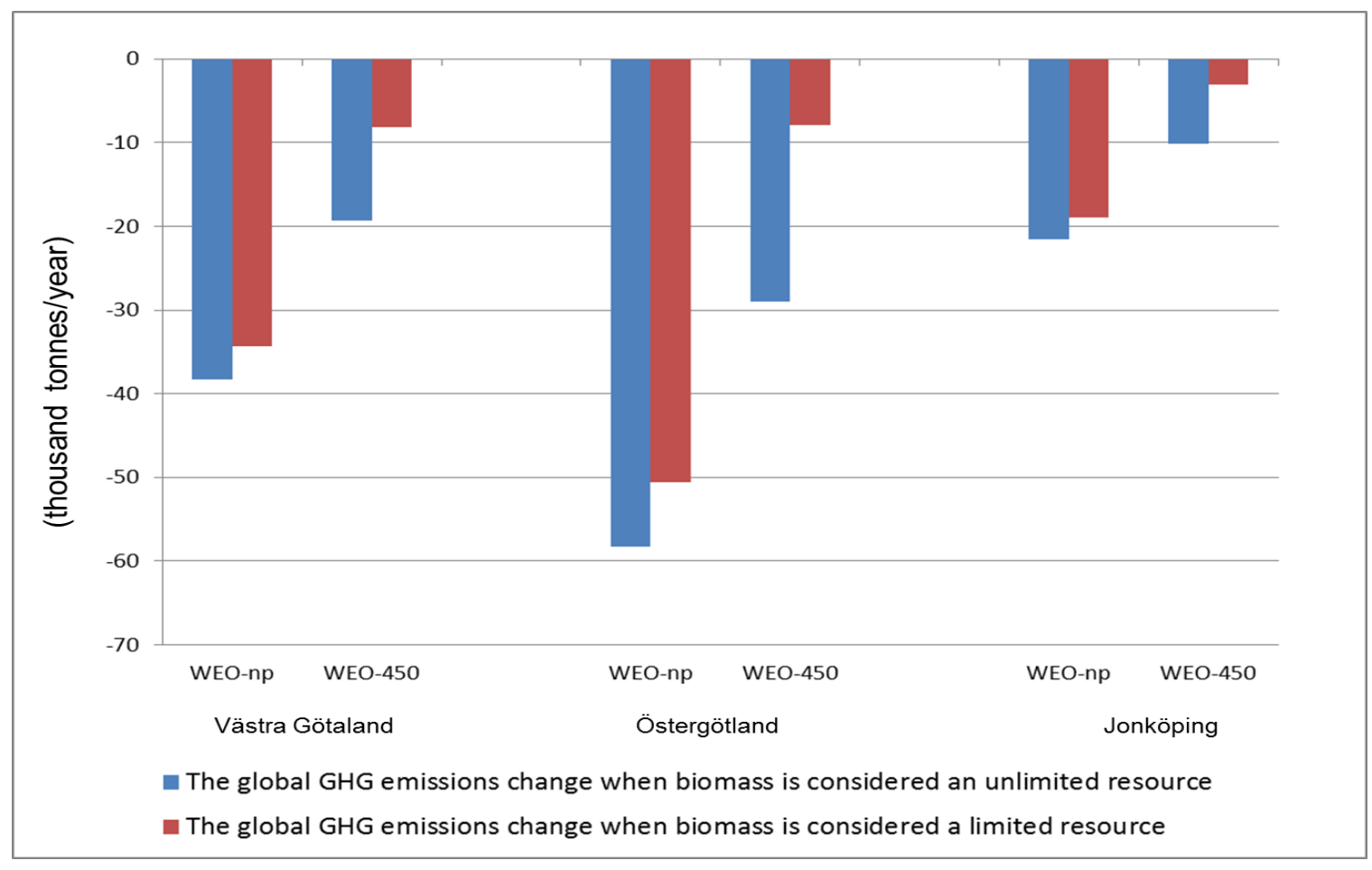

Figure 8. Annual potential change in global GHG emissions.

\section{Conclusion}

Conversion of industrial processes in to $\mathrm{DH}$, implies a possibility to decrease dependency on fossil fuels and electricity in industrial sector and leads to a more efficient operation of the DH production plants in the local DHS. This may have effects on both global GHG emissions and the primary energy use.

The production processes which can be converted to DH differ depending on the industry. The potential for converting to $\mathrm{DH}$ drying is found in the manufacture of wood, the manufacture of machinery and equipment, and in the manufacture of food products. Compared to the other production processes, drying is characterized by having the most constant demand curve over a month, regardless of working hours. The potential for converting to DH heating is found in the manufacture of food products and the manufacture of textiles. In these industries DH heating can be used for preheating water for dishwashing and washing clothes. The potential for the utilization of DH-driven 
absorption-process-cooling is found in the manufacture of chemicals and chemical products, of basic pharmaceutical products and pharmaceutical preparations, and the manufacture of rubber and plastic products. The support process in the industry, which has the highest potential to increase the utilization of the base load plants when converted to $\mathrm{DH}$, is comfort-cooling. This is due to the fact that comfort-cooling demand is at its peak during the summer when the DH demand is lowest. The introduction of DH-driven absorption-comfort-cooling would also contribute to avoiding the peak demand of electricity for compression-cooling production during the hottest summer days.

Calculations based on the estimated DH production mixes in the DHSs (see section 21) and the assumed EMSs (see sections 2.3 and 2.4) indicate that an increased use of DH in the analysed companies leads not only to lower energy use costs but also to decreased global GHG emissions. However, the potential for decreasing the energy costs for the industrial companies highly depends on the DH price, while the potential for decreasing global GHG emissions highly depends on the marginal effects of biomass use and the type of marginal electricity production.

\section{Acknowledgements}

This research was conducted under the auspices of the Energy Systems Programme at Linköping University, which is financially supported by the Swedish Energy Agency. The research was also financially supported by the Swedish District Heating Association. The financial support is gratefully acknowledged. The authors would like to express their gratitude to Patrik Holmström (of Swedish District Heating Association), Elisabeth Wetterlund (of Division of Energy Engineering, Luleå University of Technology) and Sarah Broberg Viklund (of Division of Energy Systems, Linköping University) for helpful discussions and valuable comments. 


\section{Appendix}

Table 8. Time division

\begin{tabular}{cccc}
\hline \multicolumn{1}{c}{ Day } & Hour & Day & Hour \\
\hline November - March & weekday & April - October & $06-22$ \\
weekday & $06-07$ & & $22-06$ \\
& $07-08$ & weekend, holiday & $06-22$ \\
peak day & $08-16$ & & \\
& $16-22$ & \\
& $22-06$ & & \\
& $06-07$ & & \\
& $07-08$ & & \\
weekend, holiday & $08-16$ & & \\
& $16-22$ & & \\
& $22-06$ & &
\end{tabular}

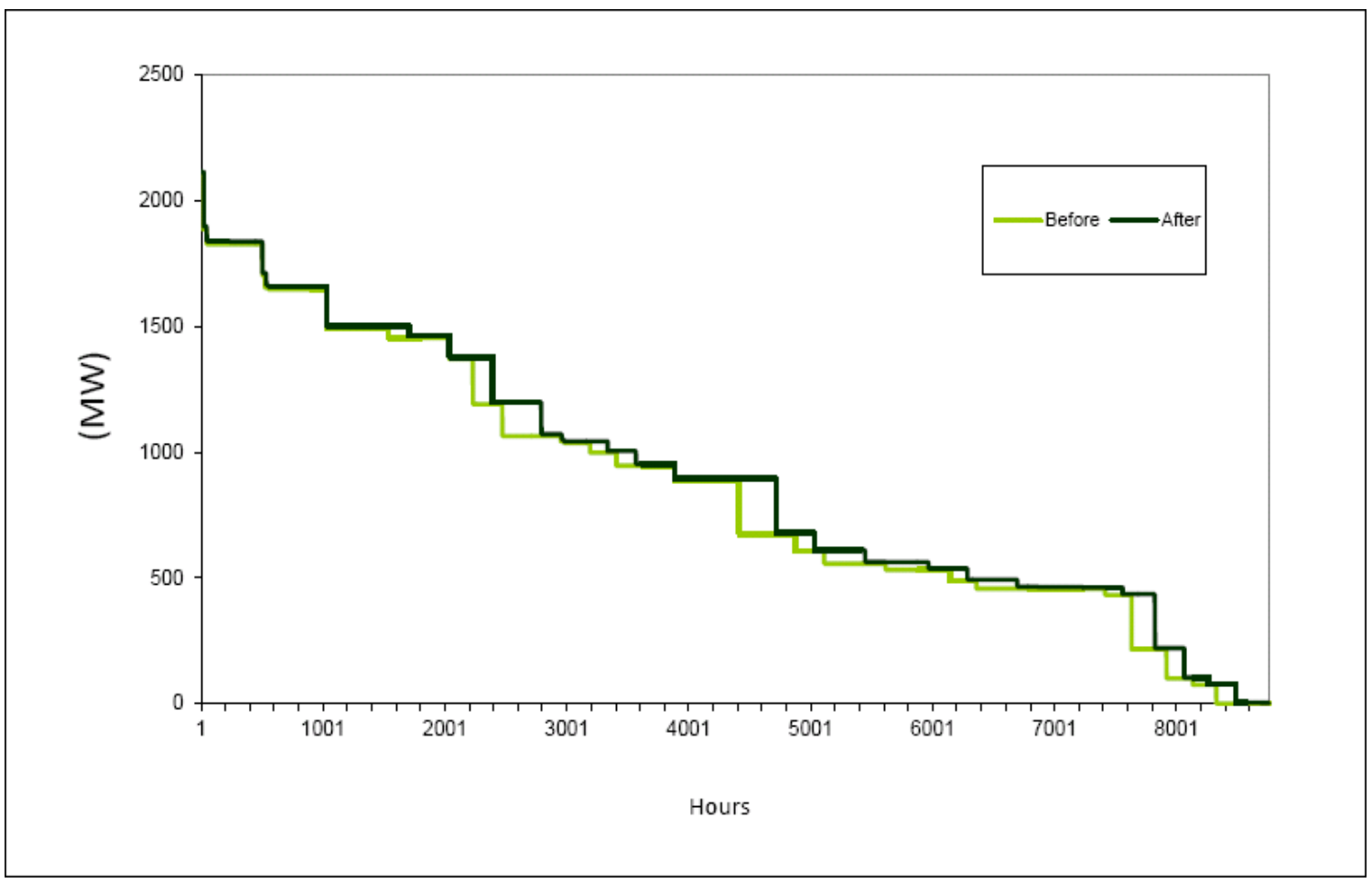

Figure 9. The load duration curve in the DHS in Västra Götaland County before and after conversion to DH in the analysed industries. 


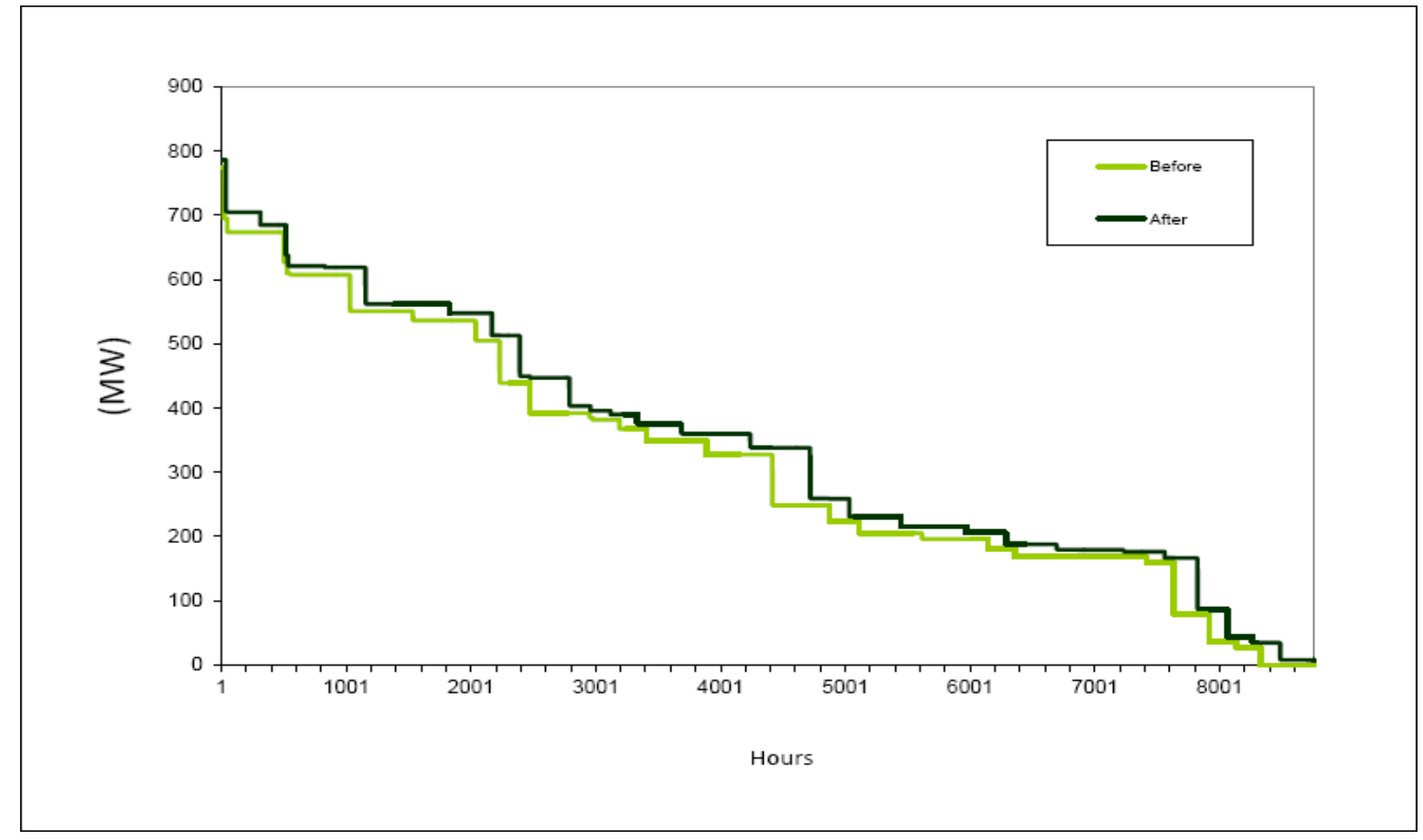

Figure 10. The load duration curve in the DHS in Ostergötland County before and after conversion to DH in the analysed industries.

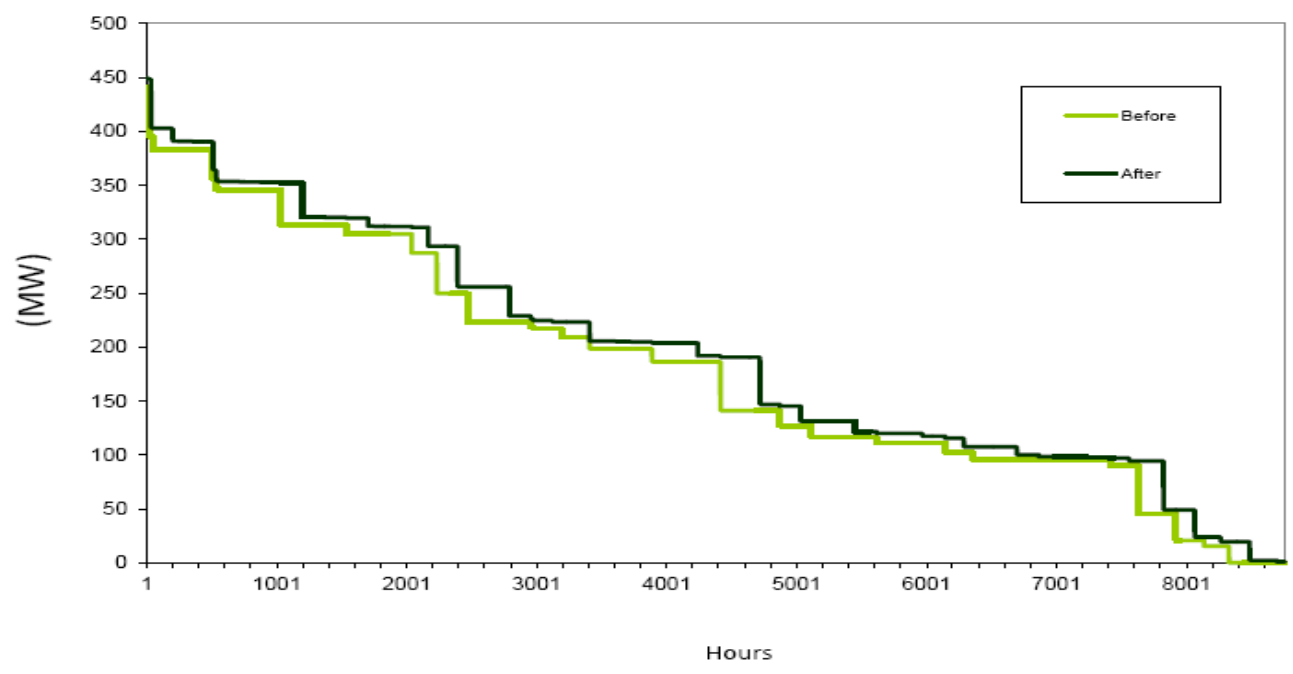

Figure 11. The load duration curve in the DHS in Jönköping County before and after conversion to DH in the analysed industries. 


\section{References}

[1] Lund H, Möller B, Mathiesen BV, Dyrelund A. The role of district heating in future renewable energy systems. Energy 2010; 35:1381-90.

[2] Münster M, Morthorst PE, Larsen HV, Bregnbæk L, Werling J, Lindboe HH, Ravn H. The role of district heating in the future Danish energy system. Energy 2012; 48:47-55.

[3] Mathiesen BV, Lund H, Connolly D. Limiting biomass consumption for heating in 100\% renewable energy systems. Energy 2012; 48:160-8.

[4] Chai DS, Wen JZ, Nathwani J. Simulation of cogeneration within the concept of smart energy networks. Energy Convers Manage 2013; 75:453-65.

[5] Gebremedhin A. Introducing District Heating in a Norwegian town - Potential for reduced Local and Global Emissions. Appl Energy 2012; 95:300-4.

[6] Hinnells M. Combined heat and power in industry and buildings. Energy Policy 2008; $36: 4522-26$.

[7] Tveit TM, Savola T, Gebremedhin A, Fogelholma CJ. Multi-period MINLP model for optimising operation and structural changes to CHP plants in district heating networks with long-term thermal storage. Energy Convers and Manage 2009; 50:639-47.

[8] Fahlén E, Trygg L, Ahlgren EO. Assessment of absorption cooling as a district heating system strategy - A case study. Energy Convers and Manage 2012; 60:115-24.

[9] Magnusson D. Swedish district heating-A system in stagnation: Current and future trends in the district heating sector. Energy Policy 2012; 48:449-59. 
[10] Broberg Viklung S, Johansson MT. Technologies for utilization of industrial excess heat: Potentials for energy recovery and $\mathrm{CO}_{2}$ emission reduction. Energy Convers and Manage 2014; 77:369-397.

[11] Kapil A, Bulatov I, Smith R, Kim JK. Process integration of low grade heat in process industry with district heating networks. Energy 2012; 44:11-19.

[12] Ådahl A, Harvey S. Energy efficiency investments in Kraft pulp mills given uncertain climate policy. Int J Energy Res 2007; 31:486-505.

[13] Frederiksen S, Werner S. District heating and cooling. Studentliteratur, Stockholom, Sweden; 2013.

[14] SEA. Energy in Sweden 2012. Swedish National Energy Administration, ER 2012:75., Eskilstuna, Sweden; 2013.

[15] Difs K, Danestig M, Trygg L. Increased use of district heating in industrial processes Impact on heat load duration. Appl Energy 2009; 86:2327-34.

[16] Trygg L, Amiri S. European perspective on absorption cooling in a combined heat and power system - A case study of energy utility and industries in Sweden. Appl Energy 2007; 84:1319-37.

[17] Difs K, Trygg L. Pricing district heating by marginal cost. Energy Policy 2009; 37:606-16.

[18] Henning D, Trygg L. Reduction of electricity use in Swedish industry and its impact on national power supply and European CO2 emissions. Energy Policy 2008; 36:2330-50.

[19] Henning D. Optimisation of local and national energy systems. Development and use of the MODEST model. Dissertation No. 559, Linköping University, Linköping, Sweden; 1999. 
[20] Henning D, Amiri S, Holmgren K. Modelling and optimisation of electricity, steam and district heating production for a local Swedish utility. European Journal of Operational Research 2006; 175:1224-47.

[21] Axelsson E, Harvey S, Berntsson T. A tool for creating energy market scenarios for evaluation of investments in energy intensive industry. Energy 2009; 34:2069-74.

[22] Axelsson E, Harvey S. Scenarios for assessing profitability and carbon balances of energy investments in industry. AGS Pathways report 2010:EU1, The Alliance for Global Sustainability, Gothenburg, Sweden; 2010.

[23] Axelsson E, Pettersson K. Energy price and Carbon Balances Scenarios tool (ENPAC) a summary of recent updates. Chalmers University of Technology, Göteborg, Sweden 2014. Available on: https://publications.lib.chalmers.se/publication/194812-energy-price-andcarbon-balances-scenarios-tool-enpac-a-summary-of-recent-updates

[24] Svensk Fjärrvärme. Statistik Bränsle och produktion 2011. 2013. Available at: http://www.svenskfjarrvarme.se/Statistik--Pris/Fjarrvarme/Energitillforsel/ (Accessed November 6, 2013).

[25] Magnusson D. Between municipal and regional planning: the development of regional district heating system in Stockholm from 1978 to 2010. Local Environment 2011; $16: 319-37$

[26] ITPS. Regional utveckling till år 2030. 2008.

[27] Difs K. National energy policies: Obstructing the reduction of global $\mathrm{CO}_{2}$ emissions? An analysis of Swedish energy policies for the district heating sector. Energy Policy 2010; 38:7775-82. 
[28] Amiri S, Trygg L, Moshfegh B. Assessment of the natural gas potential for heat and power generation in the County of Östergötland in Sweden. Energy Policy 2009; 37:496-506.

[29] Danestig M, Gebremehdin A, Karlsson B. Stockholm CHP potential—An opportunity for $\mathrm{CO}_{2}$ reductions? Energy Policy 2007; 35:4650-60.

[30] Göransson A, Sköldberg H, Unger T, Johnsson J. Fjärrvärmen i framtiden - behovet. Profu. 2009:01., Svensk fjärrvärme AB, Stockholm, Sweden; 2009.

[31] IEA (International Energy Agency). World Energy Outlook 2011. Available on: WwW.worldenergyoutlook.org

[32] Pachauri RK, Reisinger A. Climate Change 2007: Synthesis Report. Intergovernmental Panel on Climate Change; 2007. Available at:

http://www.ipcc.ch/publications_and_data/publications_ipcc_fourth_assessment_report_synh esis_report.htm (Accessed July 6, 2011).

[33] Börjesson P, Gustavsson L. Regional production and utilization of biomass in Sweden. Energy 1996; 21:747-64.

[34] Edwards R, Larivé JF, Beziat JC. Well to Wheels Analysis of Future Automotive Fuels and Powertrains in the European Context.Well to tank Reporte Appendix 1. Version 3c. European Commission Joint Research Centre, Institute for Energy; CONCAWE; Renault/EUCAR.; 2011. Available on: http://iet.jrc.ec.europa.eu/about-jec (Accessed September 10, 2012.).

[35] Djuric Ilic D, Dotzauer E, Trygg L, Broman G. Introduction of large-scale biofuel production in a district heating system - an opportunity for reduction of global greenhouse gas emissions. J. Clean. Prod. 2013; 64:552-561. 
[36] Djaeni M, van Asselt CJ, Bartels PV, Sanders JPM, van Straten G, van Boxtel AJ. Low Temperature Drying With Air Dehumidified by Zeolite for Food Products: Energy Efficiency Aspect Analysis. International Journal of Food Engineering 2011; 7.

[37] Canadian biomass magazine. (Official media partner of the "Wood Pellet Association of Canada" and "Canbio".) Drying Technology. Available on:

http://www.canadianbiomassmagazine.ca/content/view/2027/38/ (Accessed June 10, 2014).

[38] Rydstrand M, Martin V, Westermark M. Värmedriven kyla. FOU 2004:112, Svensk Fjärrvärme, Stockholm, Sweden; 2004.

[39] Zinko H, Söderberg SO, Fahlén E, Gebremedhin A. Integration av absortionskylmaskiner i fjärrvärmesystem. FoU 2004:119, Svensk Fjärrvärme, Stockholm, Sweden; 2004. 